\title{
TRENDS IN URBAN GOVERNMENT AND ADMINISTRATION
}

\author{
Daniel R. Grant*
}

INTRODUCTION

The hazards of political predictions are well known, even when based on the highly developed science of opinion sampling to forecast voting behavior only a few days in advance of an election. To undertake a prediction of the condition of urban government and administration in the year 2000 is admittedly far more hazardous, and perhaps even ludicrous, except for one important saving difference in the circumstances of prediction. The pollster must face the cold reality of actual events on election night, while the long-term forecaster may be comforted in the quite plausible hope that thirty-five years later few will note nor long remember what his predictions actually were.

Such an assignment was accepted, however, not with any thought of enjoying a brief adventure in science-fiction fantasy, but primarily in hopes that it might serve the useful purpose of compelling an examination of past and present trends in the politics and administration of the American city and a hard look at what is involved in projecting these trends into the distant future. It would be much better not to speak of this kind of analysis as "prediction," for its focus is primarily on where we have been and where we are now; but, once having agreed to make the effort, it is hardly proper to seek refuge in semantics.

\section{Some Assumptions and Caveats}

Obviously urban governmental trends are related to other trends in the United States and the world, primarily social and economic, and many trend assumptions are required as a basis for prediction. It is important at the outset to make clear what these assumptions are. The assumptions listed by Catherine Bauer Wurster in the Report of the President's Commission on National Goals ${ }^{1}$ are difficult to improve on in guessing what the socioeconomic world setting for urban government will be in the future. The great bulk of future population increases will take place in metropolitan areas, and most of this will be in the suburban fringes. The core cities within the metropolitan areas will continue their population decline, sometimes only a relative decline but in many cases an absolute one, and they will become increasingly dominated by the economically underprivileged population, principally racial and national minorities. The automobile population will in-

- B.A. r945, Ouachita College; M.A. 1946, University of Alabama; Ph.D. 1948, Northwestern University. Professor of Political Science, Vanderbilt University.

1 Wurster, Framework for an Urban Society, in Goals For AMERICaNs 225-47 (1960). 
crease; the proportion of older people will rise; expressways will become wider and more numerous; automation will cause a decline in the proportion of industrial jobs, increase employment in the urban professions and services, and shorten the work week; and finally, increased leisure time will result in a vastly accelerated demand for recreational, cultural, and transportation services.

Some caveats are in order to accompany these assumptions. Projection of present trends obviously might be incorrect if any one of several developments might occur; and, admittedly, some of them are not entirely unlikely. Who can say now whether scientific and technological changes will make it possible within the next two or three decades for the masses of commuters to fly to and from work each day? Dramatic new breakthroughs in medical research might cause a sharp increase in the life expectancy, changing the demands on local government in a multitude of ways. Even a twenty-five per cent drop in the birth rate would have strong effects upon population growth trends. Many other developments, such as "hot" war, serious economic depression, a dramatic new energy discovery, and basic changes in social values and public demands, could change drastically the picture of urban government as seen in the light of current trends. Nevertheless, in spite of all these contingencies and imponderables, just so long as they are kept in mind, it should be worthwhile to review critically what political scientists and other observers seem to be saying about where our urban government is going. We are thus following the admonition of Harold Lasswell in his 1956 Presidential Address to the American Political Science Association to scan "the horizon of the unfolding future."

\section{The Search for Trends in Urban Government}

Identifying significant trends in urban government is a difficult task, but determining which trends are still "running strong" is even more difficult. For example, most textbooks in urban government speak of the beginning of the twentieth century as an important turning point in urban political history-a kind of "beginning of the end" for the "shame-of-the-cities era" which Lincoln Steffens had described so graphically. Charles Adrian expresses the textbook consensus when he states that honesty has replaced "blatant corruption and spoilsmanship" in American city government in the last fifty years. ${ }^{2}$ How can we know whether the strong currents which took the sting out of the muckrakers' indictments are still moving in urban government in a way that will shape the future, or whether cities have merely reached a placid end of an era? Similarly, to which trend-maker shall we listen when trying to determine the growth prospects of the manager form and the mayor form of municipal government-the spokesmen for the International City Managers Association or for the United States Conference of Mayors? Has the enthusiasm of

\footnotetext{
${ }^{2}$ Churles Adrian, Governing Urban America 3, 486 (2d ed. ig6i).
} 
civic leadership for the manager plan reached the limits of its expansionist capabilities or will automation technology and the electronic revolution in management give the city manager movement its "second wind?"

The search for trends in the structuring of local government for metropolitan areas, and the appraisal of the strength of such trends, present an even more tangled web. If trends or movements consisted primarily of elaborate surveys and recommendations by professional staffs and citizens' committees, then the governmental integration of the metropolitan areas would surely be one of the strongest. Literally thousands of pages of metropolitan survey reports have been published just since World War II, citing similar problems of fragmented local government and recommending one or more of several varieties of metropolitan coordination. Yet the dismal record of adoptions of survey recommendations makes it extremely hazardous to speak of any trend toward metropolitan consolidation or coordination. ${ }^{3}$ York Willbern's recent book entitled The Withering Away of the City ${ }^{4}$ adds further warning to any who would project such a trend. On the other hand, is there justification for projecting a strong trend of increased governmental fragmentation in the face of recent unique metropolitan government experiments in Miami and Nashville and earlier ones in Baton Rouge and Toronto? Or, to complicate the matter further, is the whole concept of metropolitan community to become obsolete in a rising tide of "megalopolis"-the polynucleated "linear city" said to be growing up both on the Atlantic and Pacific coasts, as well as at other places in the United States?

A final illustration of the diffculty of identifying and assessing the strength of urban trends is found in the area of the urban political process itself. Probably more has been written in recent years on the decline of "bossism" and old-style city machines than on any other aspect of city government, both in the political science journals and in popular magazines and newspapers. But still more recently, "second thoughts" are beginning to appear among students of the party system and of urban politics. Some studies are suggesting that the old-style, boss-controlled, city machine was not so monolithic or hierarchical in form as we had imagined; and other studies suggest that we still have and will continue to have fairly dependable, disciplined, "leader-controlled" city political machines. Persuasive revisionists add to the frustrations of any realistic projection of urban political trends.

As we turn to this puzzling maze of urban trends, it will be useful to divide them into four broad subject-matter categories: the impact of science and technology on the municipal bureaucracy, the future of metropolitan government reorganization efforts, trends in intergovernmental relations with special reference to "megalopolis," and trends in the urban political process.

\footnotetext{
${ }^{3}$ See the summary and analysis of such surveys in Government Affairs Foundation, Inc., Metropolitan SuRveys: A Digest (I958).

"York Willbern, The Withering Away of the City (I964).
} 


\section{Science, Technology, and the Munictpal Bureaucracy}

A. Urban Needs and the Electronic Revolution

A kind of "revolution of rising expectations," or at least of rising demands, is taking place in our cities as they continue to swell with the population explosion. The pressure is not only for quantitative increases in such services as schools, parks, expressways, police, and water supply, but for qualitative improvements and the provision of entirely new services to meet entirely new problems and public desires. It is safe to say that, given sufficient time and the benefit of an occasional crisis situation, these pressures will become translated into new public policy for urban government, making for a larger and more burdened municipal bureaucracy.

Science and technology, especially at the level of urban government, are more often thought of as governmental "problem causers" (congestion from automobiles, noise from jet aircraft, and so on), than as "problem solvers," assisting in the executing of public policies and the provision of urban services. But one of the more dramatic technological developments of the century-electronic data processingmay well become the "wave of the future" in the planning and execution of urban functions. It was only a few years ago that electronic digital computers began to receive some attention in the field of city management, and originally perhaps primarily because it was a curiously high-speed, high-priced office machine serving jointly as a status symbol and conversation piece. From these modest, awkward beginnings with automation, Werner Hirsch predicts that the urban government administrator "may soon receive much greater help from science," and states:

Urban interaction analysis, end-product-oriented program budgeting, effectiveness analysis, and computerized information flow systems for planning and operating purposes hold promise for better decisions. ${ }^{5}$

A few pilot projects are already underway in an effort to develop metropolitan area intelligence systems, aimed at the problem of costly, time-consuming, uncoordinated methods of collecting, recording, and analyzing information needed for making sound decisions about urban planning, renewal, and related activities. ${ }^{e}$ The fact that the projects are based on the concept of the metropolitan area as a single system, even though constituent governmental units might be reluctant to concede this, has caused one writer to speak of the program as one which "has the possibility of charting a new and promising approach to metropolitan area integration."

The rewards paid by systematic decision-making based on electronic data processing have already been demonstrated in private industry and the federal government, and urban government can be expected to follow this lead. While its total potential

"Hirsch, Administrative and Fiscal Considerations in Urban Development, 352 Annals 48 (1964).

${ }^{6}$ Wegner, The Metropolitan Data Center Projects, 22 PuB. Admin. Rev. 145 (1962).

${ }^{7}$ See Hattery, EDP: Implications for Public Administration, 22 PUB. ADMrn. Rev. 130 (Ig62). 
has only begun to unfold, it is already clear that the superiority of the electronic computer over the desk calculator is of relatively minor significance when compared to its other values. As Lowell Hattery has pointed out:

The real significance is already apparent in the adoption by administrators of the biological and engineering concepts of "system," reorganization of the function and methods of data processing; a new look at decision making and the possibility of precise programming for decision making; and new sensitivity to technological change and its present and prospective effects on organization and administration. ${ }^{8}$

\section{B. Trends in Municipal Manpower}

Trends in population growth, urban service demands, and changing management technology, all have tremendous implications for the future of municipal manpower requirements. If the future is to consist of a projection of present trends in municipal manpower, the picture would seem to be a generally discouraging one. According to the findings of the Municipal Manpower Commission (MMC), urban government personnel are low on the totem pole in comparison to qualifications and morale of state and federal personnel. This Commission recently studied primarily the administrative, professional, and technical personnel in municipal government, and predicted serious shortages in these categories by 1980 . Based on an analysis of the personal careers of 1,700 such personnel, the Commission reported that

a relatively small minority has been trained either formally or informally for the posts now held. Four out of five have served in only one local government, and they complain that the prospects for advancement are slight. More than one-third are within ten years of retirement. Eight out of ten would not recommend a career in local government to their own children. ${ }^{8}$

Present municipal personnel practice was criticized by the Manpower Commission in two respects probably above all others. Recruiting efforts of city governments are described as feeble, underfinanced, unimaginative, and, in the words of the personnel directors themselves, "totally inadequate for the job to be done."10 Only one in twenty local governments was found to have any semblance of forecast of the manpower needed for even one year into the future, much less three to five, or ten years ahead. A second criticism is aimed at the independent status of civil service commissions, which are charged with obstructing the essential personnel responsibilities of municipal executives. The Commission unanimousiy recommended that they either be abolished or limited to an advisory function.

While the findings of the Municipal Manpower Commission do not necessarily describe the future municipal bureaucracy for us, they tend to confirm a general

${ }^{8}$ Ibid.

- Summarized by John J. Corson, What Are the Special Problems of Obtaining Quality in Municipal Public Service?, in Stephen B. Sweeney \& James C. Charlesworth (Eds.), Achievino Excrllence in Public Service 51-60 (American Academy of Political and Social Science, 1963). See also the full report of the Municipal Manpower Commission, Governmental Manpower for Tomorrow's Cities (1962).

${ }^{20}$ Corson', supra note 9, at 56. 
proposition that "the lower the level of American government (everything else being equal), the lower the bargaining power of the unit of government seeking to recruit and keep qualified personnel." This would seem to indicate that the municipal bureaucracy will follow, rather than lead or stay abreast of, the state and federal bureaucracies in coming years. Even so, a generally rising status of public employees at all levels of government can be expected to improve the quality, specialization, and professionalization of the municipal bureaucracy.

\section{Hegelian Synthesis for City Managers and Mayors?}

One of the strongest forces for reform in American government during the twentieth century has been the evangelistic fervor associated with the city-manager movement, beginning with only a few adoptions during World War I, growing to about 500 by $1940,1,000$ by $195^{\circ}$, and over 2,000 by 1965 . Co-evangelists until recent years have been businessmen and political scientists, who promoted the councilmanager plan as a means of bringing professionalism, scientific management, and non-partisanship to city government, as well as of eliminating "bossism" and the various undesirable elements commonly associated with it. During the past decade the writers of political science textbooks have been increasingly careful not to "endorse" any particular form of city government, partly because of doubts about the provision for political leadership under the manager plan, but more particularly because of a desire to distinguish the role of the political scientist from that of political reformer. Such organizations as the International City Managers Association and the National Municipal League continue to provide strong support for civic leaders interested in promoting the plan, and new adoptions continue to be reported at a rate exceeding one per week. In the population category of cities between 25,000 and 500,000, the manager form is more widely used than the mayorcouncil form, but only four of the twenty-one cities over 500,000 are "manager cities."

What does the future hold for the major forms of city government? It seems clear that the commission form will continue its slow but steady decline in usage by American cities. When Galveston, birthplace of the commission plan, abandoned it in I 960 in favor of the manager plan, this seemed to be a kind of symbolic coup de grace for the awkward "five-mayor plan," as its critics have labeled it. On the other hand, the mayor-council form in recent years has been undergoing a variety of reformations, innovations, and refurbishings, particularly in the larger cities. The changes include a more integrated administrative structure, stronger powers for the mayor, and, in some cases, a career "deputy mayor" or chief administrative officer similar in some ways to the city manager. It would be difficult to say whether these changes have taken place more as a natural outgrowth of urban pressures demanding stronger and more professional administrative direction of the city's affairs, or primarily as a strategic move to head off the growing competitive 
pressure to adopt the "more radical" council-manager plan. In any case, the effect has undoubtedly been to support efforts of the dominant political organizations in most of the larger cities to defeat the city-manager movement. The strengthened mayor-council form has received support from some political scientists who suggest that the elected executive is better suited for resolving the political and social conflicts of diverse groups.

In spite of some cooling of the early ardor of the manager movement, there is little evidence of an early end to its spread among American cities and no evidence at all to indicate any reduction in the total number using the plan. At present approximately one-fourth of all cities over 1,000 in population have the citymanager plan and it does not seem unreasonable to expect this proportion to rise to one-third or even to one-half of such cities by the end of the century.

Some counter-revolution in the nature and functioning of the council-manager form can be expected, however, even as it spreads to additional cities. Partly to meet the "competition" of the mayor-council plan's alleged advantages in providing political leadership, and partly because of the liberalizing influence of an increasing number of studies showing that city managers are, in actual practice, policy leaders, the council-manager plan can be expected to evolve away from its more antiseptic, apolitical form toward a more openly politicized form. Such changes might mean still further adoptions of the manager plan in the heretofore reluctant cities above 500,000 in population. In any case, the counter trends of the mayor taking on managerial characteristics and the manager taking on mayoral characteristics would seem to call for the mayoral thesis and the managerial antithesis evolving into a Hegelian synthesis.

\section{II}

\section{Governmental Structure for the Metropolitan Centrifuge}

Three "isms" of population movement-urbanism, suburbanism, and metropolitanism-are all familiar terms in the modern lexicon of public affairs, but the degree of popular familiarity with each term differs considerably. The steady growth of urban population in the United States from five per cent in I790 to nearly seventy per cent in I960 has made the urban trend common knowledge for more than a century. Suburbanism is a newer phenomenon and our familiarity with the growth of fringe-area bedroom communities has followed only a step or two behind our familiarity with the automobile. Metropolitanism is newer and less familiar still than either of the other terms. Actually it is not a precise technical term, but is a word born out of necessity to describe the political product of urbanism and suburbanism in the larger communities-one or more core cities surrounded by a loose-joined but interrelated assemblage of incorporated and unincorporated suburbs. What is the nature of this new centrifugal creature on the American scene and, more in point for this discussion, what is the governmental future for the metropolitan area? 


\section{A. The Metropolitan Area: Census View}

Because of the suburban spillover not reported in the census count of core cities, the Census Bureau had to devise new schemes to reflect the "real population" of such areas. It began reporting "metropolitan districts" in I920 and changed to two terms in I950, the "urbanized area" and the "standard metropolitan area [SMA]." In I 600 the SMA was changed to the "standard metropolitan statistical area [SMSA]." The total number of metropolitan districts (or SMAs or SMSAs) at each census from 1930 to 1960 was $96,140,168$, and 212 ; and the latter number accounted for almost II3 million of the nation's people (62.9 per cent). The bulk of the population growth has been in the suburban portions of the metropolitan areas, however, with the core cities having very modest increases or, in the case of many of the larger cities, actual losses in population. In the decade of the fifties the suburban fringe grew by 48.5 per cent while the core cities grew by only ro. 8 per cent, and nine of the ten largest cities declined in population. Los Angeles was the lone exception.

The Census Bureau also provides us a picture of the governmental units, statistically at least, of metropolitan areas in the United States. In the $2 \mathrm{r} 2$ metropolitan areas a total of $18,44^{2}$ units of government were found to exist by the 1962 census of governments. The following tabulation compares the number of units in 1962. with the number in 1957 :

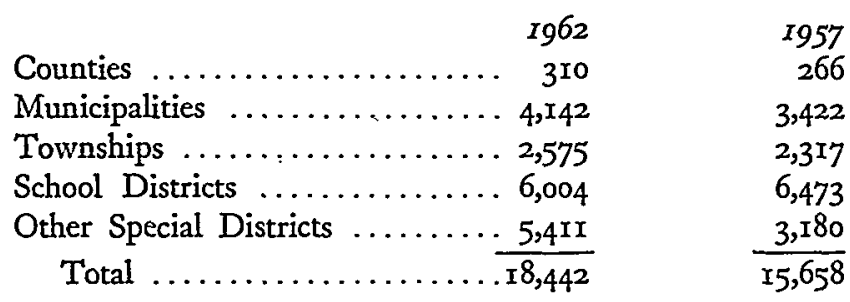

The comparison should be interpreted with caution, however, because the figures for 1962 are for a larger number of metropolitan areas than those for 1957. The number of school districts within individual metropolitan areas has almost universally declined because of the nationwide movement for the consolidation of school districts. Much of the increase in special districts and municipalities, however, is the result of establishing new units of government within existing metropolitan areas. In short, the statistical picture is one of extreme fragmentation of local government for the metropolitan area, averaging eighty-seven governments per area, and the trend is toward a greater number of special districts and municipalities, with a declining number of school districts. ${ }^{11}$ In eleven metropolitan areas the number of separate units of government totals 250 or more, and in thirteen other areas the total is at least 200.

\footnotetext{
${ }^{11}$ Based on U.S. Bureau of the Census, Census of Governments: I962, Vol. I, Governmental Organization ( $196_{3}$ ). The report shows a "net" reduction in the number of school districts in the $2 \times 2$ areas since 1957 of $x, 482$, a net increase in special districts of $x, 675$, a net increase in municipalities of 298 , and a net reduction in townships of 32 .
} 


\section{B. The Metropolitan Problem: Diverse Views}

Is this fragmentation of government in metropolitan areas a "real problem" of ever increasing intensity or is it for the most part an academic issue which offends the sense of symmetry of certain reformers desiring one government for the whole metropolis? One answer to this question is found in the scores of metropolitan surveys, undertaken by both public and private groups during the past generation, which have predominantly found governmental problems of emergency proportions. These problems might be summarized as follows: $(x)$ serious financial inequities, particularly to the disadvantage of the central city; (2) unequal services in different sections of the same metropolitan area; (3) an illogical split-up of clearly metro. politan-wide functions of government; (4) wasteful overlapping layers of local government; and (5) a weakening of democratic government at the local level by making the task of fixing credit or blame for action or inaction unduly complicated, and by permanently segregating high income suburbs and low income core cities into separate ghettos. The recommendations growing out of the surveys virtually all point toward metropolitan coordination in some form, but no single approach dominates. Generally recommended is one or more of the following proposals: annexation of the suburbs to the core city; extraterritorial powers for the core city; intergovernmental cooperation by contract; a federation of municipalities; city. county consolidation; functional consolidation; special metropolitan districts; expansion of county functions; an association of area governments; and regional planning.

In recent years, partly as a result of almost consistent failure of areas to adopt the recommendations of such surveys, "revisionist literature" in political science has begun to question some of the assumptions and findings of the metropolitan surveys. Robert C. Wood described one aspect of the re-examination as follows:

Despite our predictions, disaster has not struck; urban government has continued to function, not well perhaps, but at least well enough to forestall catastrophe. Traffic continues to circulate; streets and sewers are built; water is provided; schools keep their doors open; and law and order generally prevail. Nor does this tolerable state of affairs result from an eager citizenry's acceptance of our counsel; we know only too well that our proposals for genuine reform have been largely ignored. ${ }^{12}$

Wood points to other trends running counter to the oft-predicted disaster for the metropolis: an extraordinary period of prosperity has increased core city tax returns in spite of predicted financial decline; some core cities are finding alternative economic activities to replace departing business and industry; $;^{13}$ makeshift devices such as special districts and contractual agreements have been used to "take the heat off" of selected trouble spots; and, in less measurable ways, the trend toward

${ }^{12}$ Wood, Metropolitan Government, 1975: An Extrapolation of Trends, 52 AM. PoL. Sct. Rev. $1 \times 2$ (1958).

${ }_{13}$ See Raymond Vernon, Metropolis 1985 (1962), for such findings in the New York Metropolitan Regional Study. 
deterioration of the political process seems to have been checked by more vigorous, capable leadership in some of the larger cities. ${ }^{\mathbf{1 4}}$

In some ways a more fundamental attack on the assumptions of the metropolitan surveys has been made by questioning the concept of "one community" when applied to an entire metropolitan area. Some have suggested that metropolitan sprawl results in a "huge mosaic of massed segregation of size, class, and ethnic groups," a "crazy quilt of discontinuities." 15 Some use this as supporting evidence for the argument that it is unjust or at least illogical to consolidate all of the parts of a metropolitan area under a single government, but others simply use it as an explanation for the many negative votes in consolidation referenda.

Is the "metropolitan problem" real, therefore, or is it imaginary? Is it not possible to concede that many of the metropolitan survey reports, and certainly their publicists, overstated their case with the language of disaster, and yet still conclude that there is a strong case for restructuring the government of metropolitan areas? As Wood concludes, there are still metropolitan problems aplenty:

... ugly implications of growing segregation of classes, races, and occupations in suburban ghettos; marginal costs and wastes and inefficiencies in government finance ... . ; the overriding issue as to whether we will realize the potential, in politics, in land use, in social intercourse, in the amenities of existence which metropolitan regions promise. We may not face catastrophe, but this is no reason for countenancing one-hour commuting schedules, for permitting blight, for condoning the repellent sprawl of cheap commercial developments, inadequate parks, congested schools, mediocre administration, traffic jams, smog, pollution, and the hundred and one irritations which surround us. . .

In the end, the case for metropolitan reform, the drive for larger governments and for one community is as strong as ever. ${ }^{16}$

Charles Press comes to virtually the same conclusion after criticizing the emphasis on manhole counting and the duplication of services found in many metropolitan surveys. He commends the recent study of the New York metropolitan region by Raymond Vernon and others for its focus on the metropolitan environment as a resource for human use. The metropolitan problem is more than simply the scatteration of citizens and industry across the countryside in uneconomical and irrational ways, according to Press; it is the problem of conserving for human use the resources created by a metropolitan environment. ${ }^{17}$

\section{Trends in Metropolitan Reorganization}

If, as this writer believes, even after a thorough re-examination of the literature on metropolitan areas, a metropolitan problem of major and expanding proportions still exists, it becomes important to consider current trends in the structure of local

16 Wood, supra note 12 , at II3.

${ }^{15}$ Sec Arensberg, American Communities, 57 AM. ANThropologist II 43-62 (I955).

16 Wood, silpra note 12, at II9, 122.

${ }^{17}$ Press, Research on Metropolis: Foundation for Conservation, 22 PuB. AmMin. Rev. 88-95 (rg62). 
government in the metropolis. In the first place, what is happening in the field of annexation, the "solution" which has been pronounced "beyond hope" on so many occasions? On the surface, at least, the following tabulation of annexations since 1948 indicates a bright future for this device, with a steady increase in the area annexed annually and the number of annexing cities: ${ }^{18}$

$\begin{array}{ccc}\text { Area }(\text { Sq. miles) } & \text { Number of Cities } \\ \text { (Average per yr.) } & \text { (Average per } y r .) \\ 1948-51 & \text { I9x.4 } & 320.0 \\ 1952-55 & 307.9 & 443.0 \\ 1956-59 & 537.5 & 524.7 \\ 1960-63 & 824.6 & 776.0\end{array}$

Annexation has been used much more vigorously during the past decade than is commonly realized, and it must not be counted out for at least some of the cities of the future. Annexations of spectacular size have taken place in some states, Oklahoma and Texas in particular, with Oklahoma City having annexed approximately 553 square miles since 1959. It now has the largest area of any city in the United States with a total land area of 64 I.I square miles for its estimated population of 369,000 , compared to the Los Angeles area of 458.2 square miles and a population of 2,600,000. Further evidence of confidence placed in annexation by some states has been the establishment of local boundary review boards and no-incorporation zones around municipalities. Even so, annexation's usefulness is still limited to the unincorporated areas around cities and most of the larger cities are already totally surrounded by incorporated suburbs. Annexation cannot be expected to play a significant role in most of the larger and older metropolitan areas, but it might well play a surprising role in the structuring of the future government of the presently small metropolis.

If the existence of incorporated municipal governments in the suburban fringe is the chief obstacle to the use of annexation, what is the likelihood that the more grandiose schemes of coordination by consolidation of governments, or perhaps federation of governments, may be achieved in the next generation? Neither the opinions of political scientists nor the evidence of past and present trends would seem to offer much hope for the more radical structural reorganizations commonly labeled "Metro." The legal, financial, administrative, and above all the political, obstacles involved even in the consolidation of only two units of government, seem to be simple by comparison to the obstacles involved in achieving consolidation in the larger metropolitan areas with its hundreds of separate governments. Something of the common attitude toward the future governmental picture is seen in the Netv York Times headline in reporting the publication of Robert C. Wood's book, I400 Governments: "EXPERT PREDICTS REGIONAL CHAOS WITHIN 25

${ }^{18}$ Adapted from Bollens, Metropolitan and Fringe Area Developments in 196 3 , INT'L City Manaorns ASs'N, MUNTCIPAL YEARBiook, 1964; 'at 63 . 
YEARS: More Urban Sprawl, Noise, Traffic, Air Pollution and Blight Foreseen; AREA DISUNITY BLAMED; Study Discounts Possibility of Accord Among r,467 Local Governments." Some of the writers who speak of the virtual impossibility of achieving metropolitan consolidation, or even federation, are the ones who tend to debunk the treatment of metropolitan fragmentation as a problem in the first place. Such is not the case with Wood, however, whose discussion of the "metropolitan problem" was cited earlier. His general pessimism seems to be rooted primarily in an appraisal of the tenacity with which suburbanites cling to the mythology of the grassroots ideal of small town government, even in the metropolis. ${ }^{20}$

A few rays of hope exist, however, for those looking for some kind of area-wide local government for the metropolis in future years. One such ray is the action of such cities as Baton Rouge, Toronto, Winnipeg, Miami, and Nashville, which in the past decade or two have adopted bold proposals for metropolitan coordination involving radical departure from the status quo. The Baton Rouge action in 1947 involved a partial merger with East Baton Rouge Parish. In I953 the "Municipality of Metropolitan Toronto" was created by the provincial parliament, linking the city of Toronto and twelve suburban "satellite" cities in a federation. Winnipeg followed suit a few years later. Miami and Dade County in I957 adopted a two-tiered form of metropolitan government which incorporates, to a limited degree, the principle of federation. The latest adoption of tailor-made metropolitan government took place in Nashville in 1962 when it consolidated with Davidson County into a single government with an expandable "urban services district." To this list might be added the sweeping governmental reorganization for Greater London, adopted by Parliament in $\mathrm{Ig}_{3}{ }_{3}$ to create an almost completely new two-level governmental system over 700 square miles and more than eight million residents.

It should be remembered that the Toronto, Winnipeg, and London reorganizations were accomplished by action of the central government without a vote of the constituent local units, a method not traditionally available to metropolitan reformers (although within the state's ultimate authority) in the United States. But it is not entirely beyond the realm of realism to speculate about the possible impact of Baker v. Carr and of the more urban-minded state legislatures which will no doubt follow in its wake on the structure of government in metropolitan areas. Granted that legislative reapportionment will in some cases augment suburban power more than core city power, it is entirely possible that some state legislatures will become far more responsive to political forces desiring consolidation or federation of local governments in the metropolitan area. The dramatic history of the successful movement for consolidating local school districts in the United States, with its generous use of both the "carrot and the stick" by the state governments, should give pause to

\footnotetext{
${ }^{10}$ N.Y. Times, July I7, I96I, p. I, col. I. Wood's volume is one of nine resulting from the New York Metropolitan Regional Study and published by the Harvard University Press.

${ }^{20}$ See Robert C. Wood, Suburbia: Its People and Their Politics (iǵ59).
} 
those who say the metropolitan consolidation in future years is either impossible or constitutes a totally unrealistic alternative. Without suggesting that there will be an epidemic of consolidated "Metro" governments within the next thirty-five years, this writer is willing to predict that there will be at least a baker's dozen among the smaller and medium-sized metropolitan areas, and certainly more than were adopted during the past thirty-five years.

A baker's dozen does not make much of a dent among the 212 metropolitan areas, however, even when reinforced by the number which may keep up with suburban sprawl by means of annexation. What, then, is to be the governmental picture for the bulk of the metropolitan areas in future years? The trends running strongest now include the creation of special districts to handle specific problems across boundary lines, an expanded role for the urban county in serving both incorporated and unincorporated areas, the development of more elaborate programs and institutions for comprehensive regional planning, and (related to the latter) the organization of voluntary associations of area governments in the various metro-

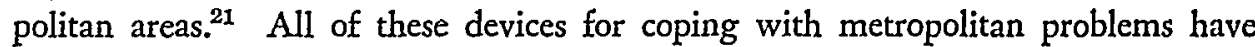
at least one thing in common-they assume the continued existence of governmental fragmentation and even the likelihood of its increase. If the metropolitan areas in 2000 A.D. are to be larger and more numerous than they are now, with an even greater proliferation of separate governments, then is the most accurate prediction for them one of governmental paralysis and "regional chaos," as suggested by the New York Times headline? The answer to this question requires a consideration of the "vertical aspects" of intergovernmental relations (federal-state-local) as opposed to the "horizontal aspects" (inter-local relations) which have been our major focus thus far, and we turn to this subject now.

\section{III}

2000 a.d.: The Intergovernmental Megalopolity

The increasing company of authors of books and articles dealing with the "dying city" theme in recent years cannot be lightly dismissed as ivory-towered alarmists. Willbern's The Withering Away of the City, E. A. Gutkind's The Twilight of Cities, ${ }^{22}$ and Bernard Weissbourd's recent article in the Saturday Review, "Are Cities Obsolete?", 23 are just three examples of many which, while dealing with various aspects of the city, all include a common theme: the nature of the city and of its government is changing before our very eyes and its actual survival in anything like its present form is quite doubtful. Willbern's thesis and forecast for local government are especially relevant to our discussion. The major role of the municipal

\footnotetext{
${ }^{22}$ For current trends in the use of such devices, especially the growth and activities of associations of area governments, such as "ABAG" and others, see Bollens, supra note 18, at 57-60.

${ }^{22}$ Both published by Free Press of Glencoe, New York, in 1962.

${ }^{23}$ Dec. 19, 1964, pp. 12-15, 66.
} 
corporation during the past century is seen as withering steadily in future years as its population moves outward and across county and even state boundary lines. It will become only one component among many in the new model describing American local government-the "many" consisting of a network of special districts, some single-purpose and some multi-purpose, several counties with increasing but segmental responsibilities, an assorted spectrum of public and private utility-type enterprises, and an elaborate variety of cooperative arrangements with higher governmental levels.

Where will the self-governing urban community be in this future model of local government? In view of the prospects for the development of the Gottman-style megalopolis in several regions of the United States (encompassing several metropolitan areas merged into each other), it is necessary to ask also where the selfgoverning metropolitan community will be. York Willbern considers and rejects several possible locales:

It certainly is not the traditional central city, which is largely being lost in a jumble of other units and arrangements. It is hardly to be found in new satellite suburban communities, which serve some purposes and functions but not enough. A new metropolitanwide, self-governing community is likely to be a will-o'-the-wisp in most circumstances, beckoning the crusader, but rarely if ever attained. The . . . territorial units, primarily counties, will hardly serve as the vehicle for truly integrated communities, particularly because the territorial boundaries are largely immutable and frequently have only coincidental relationships to the areas of denser settlement. ${ }^{24}$

Scott Greer and David Minar recently asked basically the same question in pointing to the explosion and disappearance of the local community as we have known it. ${ }^{25}$ In an era when Americans are beginning to live in many overlapping "communities," and when geographic "community" may mean less than vocational, social, or recreational community, old notions of community no longer jibe with living patterns.

The answer to the question of where the old, clearly defined, self-governing community will be in 2000 A.D. is simply that it will be lost in the shuffle of the intergovernmental megalopolity, at least for the vast majority of people. New definitions of community will have to be developed. As Willbern points out, "where patterns of urban living spread over the landscape, 'community' is hardly unitary, and selfgovernment must probably be as complex as our interrelationships."26

A word of caution is in order, lest we be carried away completely by our logic. There can be no doubt that, even while industrialization, suburbanization, and metropolitanization increasingly constitute the realities of American life, there will be a dogged persistence of the agrarian myths in popular political attitudes. As

24 WILlBERN, op. cil. supra note 4, at 122.

${ }^{25}$ Greer \& Minar, The Political Side of Urban Development and Redevelopment, 352 ANNaLs $72-73$ $(1964)$.

${ }^{20}$ WILLBERN, op. cit. supra note 4 , at 123. 
George Blair reminds us, we are experiencing a decline in rural population without much decline in the rural shibboleths about "big city government"-that it is more impersonal and less human, less subject to popular control, more "politics-ridden," more irresponsible, inflexible, bureaucratic, and less democratic generally than "rural, grass-roots government."27 Thus, people will continue to talk about the local community somewhere in megalopolis long after sociologists have concluded that the territorially-based local community in megalopolis has ceased to exist. For the student of political behavior, the myth may be as important as the fact, particularly as it affects the structure of local government.

It is against this backdrop of increasing fragmentation of urban government-the bad fences that make bad neighbors-and a strong tendency toward disappearance of the local community that the coordinative and leadership roles of the national and state governments become virtually if not absolutely inevitable. Robert Connery and Richard Leach made this clear in declaring that the "greatest need in the cities today is not water or sewers, or wider streets, or more schools, or housing, important as they are. What is needed most is drive, organization, and leadership.... The federal government has a clear responsibility to act. ..."28

New and elaborate programs involving federal-state-local cooperation can be expected to seek the kind of areal coordination once provided by the municipal corporation before the suburban explosion put an end to that. Charles Adrian predicts that our tendencies toward a "mass society," with fewer regional differences, will soften the image of Washington or the state capital imposing policy on local government and will reinforce the trend toward a common set of objectives among federal, state, and local employees. ${ }^{29}$

The growing influence of the career bureaucrat, the expert staff man, the professional, will be a natural result of the growing complexity of relationships, vertical and horizontal, in the "intergovernmental megalopolity." Even our comparatively brief experience with urban renewal programs, and with the newer anti-poverty program, make it abundantly clear that only highly specialized personnel can carry on the negotiations necessary to comply with the elaborate system of policies and regulations involved.

The number of urban-oriented proposals in the President's State of the Union address in 1965 can only lend support to predictions of more federal and state involvement in the metropolis and a more complex set of intergovernmental relationships. The role of the urban planner, whose training is calculated to make him concerned primarily with the general interest and the broader viewpoint, is being given greater influence and prestige by the various "planning strings" attached to

\footnotetext{
${ }^{27}$ Grorge S. Blatr, American Local Government 590 (1964).

${ }^{28}$ Robert H. Connery \& Ruchard H. Leach; 'The Federal Government and Metropolttan Areas 238 (1960).

${ }^{20}$ ADRIAN, op. cit. supra note 2, at 493.
} 
the newer programs. This can only be augmented further as new assistance programs are added..$^{30}$

One other characteristic of the intergovernmental megalopolity will be the increasing reliance upon joint federal-state-local arrangements for the provision of necessary revenue to provide urban services and controls. In spite of movements in many states, which have been strongly supported by the U.S. Advisory Commission on Intergovernmental Relations, to give cities a broader tax base than the general property tax, we can expect the trends toward state grants-in-aid and shared taxes and toward increasing federal assistance to remain dominant. The obstacles to local raises in taxes include not only the difficulties of an increasingly fragmented local government structure, but the even more basic disinclination of citizens to associate taxes with services. ${ }^{31}$ We can expect a continuation of the trend toward levying the taxes at the higher levels of government and spending and administering the funds at the lower levels.

\section{IV}

\section{Trends in Urban Politics}

The preceding discussion has been concerned in large measure with the formal structure of future urban government, but any consideration of urban trends would not be complete without examining trends in urban politics-the process of influencing public decision-making. So we turn now to a consideration of the question of whether there are discernible trends in the process of urban politics which will constitute the basis for future city government.

\section{A. A "New Political Ethos" for the City?}

Edward C. Banfield and James Q. Wilson, in the concluding chapter of their City Politics, state that the most important changes occurring in city politics today are the changes in the urban "political ethos."32 They refer to the increasing absorption of the immigrant lower class into the middle class and the profound effects of this on the outlook of the electorate. The major transformation in the newcomers to the middle class is said to be their acceptance of the "middle class ideal": politics as a search for the "public" interest-the interest of the community "as a whole"-and preference for government by technical experts and statesmen, not by politicians. This new political ethos is said to provide new support for such older institutional reforms as non-partisanship, at-large elections, the city-manager plan, master planning, and metropolitan area reorganization, as well as new opposition to "bossism" and the smoke-filled room.

\footnotetext{
${ }^{80}$ For an excellent discussion of trends in the relationship of federal policies to urban planning, see Beckman, Our Federal System and Urban Development: The Adoption of Form to Function, 29 J. AM. INSTITUTE OF PLANNERS 152-67 (1963).

${ }^{81}$ See ADRIAN, op. cit. supra nate 2, at 494.

${ }^{32}$ Edward C. Banfield \& James Q. Wilson, City Politics 329 (1963).
} 
The one troublesome part of this analysis by Banfield and Wilson is that it seems to overlook strong evidence to the contrary in most core cities in the United States, i.e., the exodus of the middle class from core city to suburbs, leaving the core city to the swelling non-white population. They acknowledge this seeming contradiction, and the congeniality of "the old-style politics of the boss and machine" to the lower class, but contend that

... the nationally growing middle class has shown that it will use its control of state and federal governments-and particularly of law enforcement agencies and of special districts within the metropolitan areas-to withhold the patronage, protection, and other political resources that are indispensable to the growth of political machines in the central cities. This means that the lower class will have to play politics of a kind that is tolerable to the middle class or not play it at all. ${ }^{33}$

\section{B. City Bossism: Decline or Persistence?}

The decline of bossism and of old-style city politics has been widely reported by political scientists in recent decades, although it has not been explained in quite such simple terms as the lower-class absorption theory described above. A variety of causes are said to have contributed to the decline of bosses, such as the growth of professional welfare programs, the drying up of patronage "plums," and the growth of a number of devices for more direct democracy and a more enlightened electorate. The disappearance of such colorful bosses as Frank Hague, James Curley, Tom Pendergast, and Ed Crump, along with their well-disciplined machines which operated clearly on the basis of service for a price, is rather imposing evidence of a dramatic decline in old-style city politics.

But is the decline permanent? Cautious predictions of a revival of certain aspects of machine politics in certain kinds of settings are being made by some observers. ${ }^{34}$ Robert A. Dahl's research interest in "who governs New Haven?" resulted in his upgrading the importance of modern machine politics in that city, and Richard $\mathrm{T}$. Frost's study of eight New Jersey counties revealed that party leaders were performing a great many of the traditional party services there in $1957 .^{35}$ Still others point to the growing non-white proportion of the population of metropolitan core cities as the basis for a new, dependable political machine, as suggested above.

Two new-style urban political patterns are described by Fred Greenstein: ( $I$ ) the politics of non-partisanship in approximately two-thirds of American cities above 25,000 in population, with varying degrees of conformity in actual practice, and (2) the new "party club" phenomenon, organized within some urban political parties, usually characterized by a youthful and ideologically oriented zeal. He cautions that these cannot be considered the future pattern of urban politics, however, but only single manifestations in a panorama of urban political practices. "The

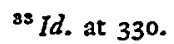

${ }^{34}$ See Greenstein, The Changing Pattern of Urban Party Politics, 353 Anwals 1-13 (1964).

${ }^{35}$ Robert A. DAHL, Who Governs? (196r); Frost, Stability and Change in Local Politics, 25 Pun. OPIN. Q. 23I-32 (I96r). 
degree to which old-style urban party organizations will continue to be a part of this panorama is uncertain." 36 Perhaps the safest prediction is that the future pattern of urban politics will be a blending of elements of the old and the new.

\section{Rotten Boroughs in 2000 A.D.}

One problem of contemporary urban politics-the struggle for more proportional representation of urban citizens in the state and national legislative bodies-may well be replaced by a somewhat different version of it in decades to come. The area of greatest conflict could be the representational structure of the various area-wide metropolitan authorities, special districts, and occasional metro-type governments which will increasingly have core city and suburban clienteles. The democratic difficulties of excessive autonomy for such agencies, of equal representation for each unit of government, of representing governmental bodies rather than the electorate directly, and of excessive dominance by the core city, are just a few aspects of this problem which may move into more prominent billing in urban politics. ${ }^{37}$

\section{V}

\section{Conclusion: Is Urban Development Beyond the Reach of Government?}

It is presumptuous, indeed, in these concluding comments to raise such a fundamental question as whether the political variable is important in urban development, but in view of its obvious relevance it would be even worse to exclude it. On the one hand, some believe that the fate of planned urban development and redevelopment depends largely on the political system. Speaking of urban renewal, Greer and Minar recently described many of the negative effects of the politicalgovernmental structure:

Urban renewal is limited by the dichotomy of public and private control, tension between federal and municipal agencies, division of power between different federal agencies, and fragmentation of power at the local community level. . . .

Out of this diffusion of responsibility comes a curious rigidity, not a rigidity of program but a rigidity of process that enervates program. . . . Any one or combination of these may develop the power to revise, delay, obfuscate, or forbid action. . . . It safeguards stasis. ${ }^{38}$

The clear implication of this kind of statement, and of most proposals for governmental reorganizations, is that the political variable is important in urban development and that alternative governmental policies and programs do make a significant difference. Banfield and Wilson apparently disagree, at least with respect to "the most fundamental problem of the central cities and of the older suburbs-one that constitutes a life-and-death crisis for them. ..." The spread of

\footnotetext{
${ }^{86}$ Greenstein, supra note 34 , at 13.

${ }^{37}$ See Arthur W. Bromage, Political Representation in Metropolitan Agencies (1962).

${ }^{38}$ Greer \& Minar, supra note 25 , at 62,65 .
} 
lower-class slums ". . . cannot be 'solved,' or even much relieved, by government action at any level," they contend, and they downgrade the role of government more specifically by stating:

There is little that government can do about this. The forces that are at work-especially changes in technology, in location of industry and population, and in consumer tastes and incomes-are all largely beyond the control of government in a free society. Given these restraints, the future of the cities is probably beyond the reach of policy. ${ }^{30}$

Greer and Minar are not so pessimistic and do not discount the possibility of radical experimentation in urban governmental structure in the future, as unlikely as it may now seem. ${ }^{40}$ They point out that the United States does have a tradition of experimentation, particularly in the original adoption in spectacular fashion of our "untested" organizational forms-federalism, separation of powers, the Presidency, and judicial review. Robert Wood also dissents in his 5400 Governments from some of the economic determinism implied in the New York Metropolitan Regional Study reports, and argues that a metropolitan polity would control and guide the forces that some economists seem to regard as impersonal and perhaps even unchangeable.

Only the naive would contend that massive change in the polity commensurate with the massive changes in urban ecology is very likely. But only the most cynical would say that the achievement of bold invention for the American metropolis is impossible. If the past generation was able to accomplish such monumental political inventions as the Tennessee Valley Authority and the Marshall Plan, is it more difficult for the coming generation to invent and achieve workable local governments for metropolitan areas? In either case, fragmentation or integration, the structure and process of urban government can be expected to play a significant role in shaping urban development and redevelopment.

\footnotetext{
${ }^{39}$ BANFIELd \& WilsoN, op. cit. supra note 32 , at 344 . They agree here with the clear implication of Raymond Vernon, The Myth and Reality of Our Urban Problems (ig62).

${ }^{\star 0}$ Greer \& Minar, supra note 25, at 7o.
} 